\title{
KAJIAN SEMIOTIK DALAM NOVEL NY. TALIS (KISAH MENGENAI MADRAS)KARYA BUDI DARMA
}

\author{
Siti Ekta Budianti \\ SDN Kebonsari 1 Tuban \\ Jl. Gajah Mada No. 20 Kecamatan Tuban Kabupaten Tuban \\ Hp:081554779486; Pos-el: sitiektabudianti@gmail.com
}

\begin{abstract}
This research is backed up by the desire to understand and interpret the semiotic meaning in Ny. Talis (Kisah Mengenai Madras) novel by Budi Darma. The purpose of this study is to describe: (1) hermeneutic code; (2) semantic/semes code; (3) symbolic codes; (4) proaretic code, and; (5) cultural codes in Ny. Talis (Kisah Mengenai Madras) by Budi Darma. The theory used to analyze the data is Roland Barthes' semiotics which focuses on semiotic codes. The approach used is poststructural semiotics by applying heuristic and hermeneutic semiotic reading methods. Research data in the form of dialog quotes, words, sentences, and paragraphs that are related to the focus of research on semiotic codes. research data sources come from Ny. Talis (Kisah Mengenai Madras) by Budi Darma (1996) published by Balai Pustaka.The results of the research and discussion show that the semiotic codes in Ny. Talis (Kisah Mengenai Madras) novel there is a lexias fragment that connects five semiotic codes. Liaison lexias is nothing but the meaning of signification about death and matters related to death. In addition, the reality of life refers to death.
\end{abstract}

Keywords: Semiotic, Code, and Novel Ny. Talis (Kisah Mengenai Madras).

Abstrak: Penelitian ini dilaterbelakangi oleh keinginan untuk memahami dan menafsirkan makna semiotik dalam novel Ny. Talis (Kisah Mengenai Madras) karya Budi Darma.Tujuan penelitian ini untuk mendeskripsikan: (1) Kode hermeneutik; (2) Kode semes/semantik; (3) Kode simbolik; (4) Kode proaretik, dan; (5) Kode kultural dalam teks novel Ny. Talis (Kisah Mengenai Madras) karya Budi Darma.teori yang digunakan untuk menganalisis data adalah Semiotika Roland Barthes yang memfokuskan pada kode-kode semiotik. Pendekatan yang digunakan adalah semiotik postruktural dengan menerapkan metode pembacaan semiotik heuristik dan hermeneutik. Data penelitian berupa kutipan dialog, kata-kata, kalimat, dan paragraf yang memiliki keterkaitan dengan fokus penelitian kode-kode semiotika. Sumber data penelitian berasal dari novel Ny. Talis (Kisah Mengenai Madras) karya Budi Darma (1996) yang diterbitkan oleh Balai Pustaka.Hasil penelitian dan pembahasan menunjukkan bahwa kode-kode semiotik dalam novel $N y$. Talis terdapat fragmen leksialeksia yang menghubungkan lima kode semiotik. Leksia penghubung tidak lain adalah makna pertandaan tentang kematian dan hal-hal yang berkaitan dengan kematian. Selain itu, realitas kehidupan yang mengacu pada kematian.

Kata kunci: Semiotik, Kode, dan Novel Ny. Talis (Kisah Mengenai Madras) 


\section{PENDAHULUAN}

Sastra dan kehidupan tidak dapat dipisahkan. Keduanya memiliki hubungan yang sangat erat. Sastra adalah inspirasi kehidupan yang diwujudkan dalam karya sastra. Hal ini sejalan dengan teori mimesis (tentang seni sastra) yang dikemukakan Plato dan kemudian disusul pendapat Aristoteles, sastra merupakan cerminan kenyataan (Luxemburg, Dkk., 1992:17;Endraswara, 2011:78).

Cipta sastra bukan hasil dari ilham tetapi juga hasil dari pemikiran dan kesadaran pengarang. Berdasarkan hasil penelitian secara ilmiah diakui bahwa ilmu sastra bediri sendiri secara otonom di samping ilmu bahasa. Dengan demikian bahasa sebagai alat, hal yang paling penting adalah apa yang disampaikan bahasa itu (Widyatwati, 2015:58).

Berdasarkan pemahaman tersebut, karya sastra menjadi unik. Banyak hal yang diserap dalam karya sastra. Penyerapan dari lingkungan sosial, budaya, dan seni yang lain menjadi kompleks karya sastra tersebut. Dari kompleksitas semacam itu, karya sastra menjadi objek yang menarik untuk diteliti secara ilmiah. Penelitian yang bukan sekadar penelitian, akan tetapi dapat diambil manfaat timbal balik antara pengarang dengan peneliti dan penikmat sastra.

Karya sastra yang diciptakan oleh pengarang memanfaatkan media bahasa baik secara eksplisit maupun implisit. Media bahasa mengambil peran yang penting dalam penyampaian makna karya sastra kepada pembacanya. Penyampaian semacam itu, baik berupa tanda atau kode-kode yang ada di balik tanda.

Salah satu pengarang yang menciptakan karya-karya sastra penuh dengan tanda-tanda atau kode-kode baik kode budaya, simbolik, atau hermeneutik adalah Budi Darma. Bahkan beberapa karyanya menjadi karya fenomenal. Salah satunya adalah novel $\mathrm{Ny}$. Talis (Kisah Mengenai Madras). Novel Ny. Talis (Kisah Mengenai Madras) karya Budi Darma sering dikaji secara akademis, seperti yang dilakukan olehMoch. Ichlasul Yulianto (2015) bertujuan untuk memahami (1) id, ego, dan superego.

Berdasarkan hubungan antar unsur, novel $\mathrm{Ny}$. Talis mengungkapkan tanda-tanda yang memiliki makna khusus. Di samping tanda-tanda, dibalik tanda muncul kode-kode. Untuk memahami makna struktur tanda dan kode-kode dalam novel $\mathrm{Ny}$. Talis dibutuhkan landasan teori. Salah satu teori yang mengungkap makna dalam karya sastra adalah teori semiotik. Teori semiotik yang digunakan dalam penelitian ini adalah teori semiotik Roland Barthes.Pemahaman terhadap makna sebuah karya sastra harus memperhatikan tanda-tanda, kode-kode, yang terdapat dalam karya sastra.Menurut Barthes (2002); Piliang, (2012:350), jaringan struktur yang membangun sebuah teks sastra didasari oleh lima kode: hermeneutik, semes, simbolik, proaretik, dan kode kultural. Kode-kode tersebut merupakan jaringan struktur yang saling berkaitan di dalam teks.

Sejauh ini, kajian tentang novel $N y$. Talis masih belum banyak dilakukan. Kalaupun ada, bukan kajian semiotik. Alasan pemilihan objek berdasarkan pada beberapa faktor. Pertama, judul Ny. Talis ( Kisah Mengenai Madras) adalah judul yang unik. Keterangan tambahan dalam kurung yaitu (Kisah Mengenai Madras) mengandung tekateki yang memiliki daya tarik tersendiri. Kedua, tema yang disajikan dalam tema yang sederhana, karena membicarakan masalah yang selalu dialami oleh setiap manusia yaitu kegelisahan. Ketiga, konsistensi dan integritas Budi Darma 
(pengarang) terhadap penciptaan karya sastra yang bertema tentang kegelisahan manusia, mampu mendokumentasikan pengalaman batin yang sederhana menjadi istimewa sehingga mampu menampilkan pikiran-pikiran di luar sadar sebagai bagian integral dari karya sastra.

\section{METODE PENELITIAN}

Penelitian ini merupakan penelitian kualitatif naratif yang dirancang menggunakan pendekatan semiotik postruktural. Piliang (2012:247) menggunakan istilah hipersemiotika. Penekanan pendekatan semiotika postrukturalisme (hipersemiotika) adalah mengkaji elemen-elemen yang melampaui teks, tanda, struktur, kode, dan realitas untuk menemukan kode-kode baru yang mengaturnya.

Sumber data penelitian ini adalah novel karya Budi Darma Ny. Talis (Kisah Mengenai Madras) yang diterbitkan oleh Balai Pustaka. Data penelitian ini berupa kata, kalimat, dan paragraf, serta dialog tokoh yang berasal dari sumber data novel Ny. Talis (Kisah Mengenai Madras) karya Budi Darma.

Teknik pengumpulan data penelitian menggunakan teknik BSC (baca, simak, dan catat) (Ratna, 2010:245-246). Teknik analisis data dalam penelitian ini menggunakan teknik analisis pembacaan heuristik dan hermeneutik. Menurut Suhariyadi (2014:305), teknik analisis semiotik menggunakan teknik analisis tanda semiotik tingkat pertama (denotatif, linguistik) dan analisis sistem tanda tingkat kedua (konotatif, semiotik).

\section{HASIL PENELITIAN DAN PEMBAHASAN}

Menurut Piliang (2012:162), dekonstruksi teks sastra dilakukan dengan memecahnya menjadi beberapa bagian (lexias) untuk dikaji, memberinya nomor dan kemudian merekonstruksinya menjadi 48 tema. Dari 48 tema itu, Barthes menghasilkan konstruksi lima macam kode berbeda: kode hermeneutik, semantik, simbolik, proairetik, dan kultural.

\section{Kode Hermeneutik}

Menurut Astika (2014:16), kode hermeneutik adalah kode yang mengandung unit-unit tanda yang secara bersama-sama berfungsi untuk mengartikulasikan dengan berbagai cara dialektik pernyataan respons, yang di dalam proses jawaban atau kesimpulan (cerita) ditangguhkan atau mengalami penundaan sehingga menimbulkan semacam enigma (teka-teki).

\section{Kisah Tentang Madras}

Di dalam kisah kelahiran Madras terdapat jawaban yang ditunda yaitu asalusul Madras, termasuk ayah Madras yang masih menjadi misteri. Misteri ayah Madras menjadi salah satu suspense dalam cerita. suspense sebagaimana bagian dari alur mempunyai peran sangat penting, yaitu membangun konflik dari peristiwa-peristiwa ketegangan yang ada.Stanton (2012:26) menegaskan bahwa alur merupakan rangkaian peristiwa-peristiwa dalam sebuah cerita. peristiwa-peristiwa tersebut memiliki hubungan kausal. Hubungan kausal menimbulkan ketegangan (suspense) secara terus menerus hingga akhirnya menjadi stabil kembali.

"Saya sering bertanya kepada diri saya sendiri: "benarkah saya anak Abdul Murod Markasan pedagang kain? "(Darma, 1996:9).

Dua elemen dasar yang membangun alur adalah konflik dan klimaks. Setiap karya fiksi setidaktidaknya memilki konflik internal yang hadir melalui hasrat tokoh itu sendiri atau 
konflik tokoh dengan lingkungannya (Stanton, 2012:31).

\section{Kisah Misteri Ny.Talis}

Kode hermeneutika mengenai kecantikan Ny. Talis akan membawa pada persoalan lain. Laki-laki yang mengincar kecantikan Ny. Talis tidak lain adalah laki-laki iblis yang hanya menginginkan kekuasaan atau menguasai Ny. Talis. Termasuk suami Ny. Talis sendiri dikatakan Iblis. Pernyataan tersebut didukung dengan cara suami Ny.Talis memperlakukan Ny. Talis yang sangat lembut, mengalah, tetapi sebenarnya adalah malapetaka bagi $\mathrm{Ny}$. Talis. Suami Ny. Talis lebih puas Ny. Talis dipanggil Ny. Talis. Bukan menggunakan nama suami Ny. Talis, sebagaimana data berikut ini. "Ny. Talis sebagai Ny. Talis. Biarlah semua insan mengenal kamu sebagai Ny. Talis, tanpa mengenal saya. Kalau toh orang-orang mengenal saya, biarlah mereka mengenal saya sebagai suami $\mathrm{Ny}$. Talis. Saya puas." (Darma, 1996:95).

Kalau dia, yaitu Ny. Talis, sudah melempar seluruh pakaian-pakaiannya, dan membolak balik tubuhnya di depan cermin, tahulah dia, tidak mungkin baginya menyembunyikan kesengsaraan. Bekas cakaran, bekas gebukan, bekas tendangan, dan entah apa lagi, tidak mungkin memberi dia hak untuk menyatakan bahwa dia bahagia(Darma, 1996:96).

Di akhir cerita, hubungan kisah beberapa tokoh dalam cerita dibuat sedemikian rupa agar pembaca lebih santai dalam memahami cerita. Hal ini dikarenakan, bukan hubungan antartokoh dalam cerita yang disampaikan dalam cerita melainkan penanda hubungan dalam cerita. Penanda-penanda hubungan dalam cerita tersebut yang sengaja dimunculkan penulis adalah burung aneh, kematian dan hal-hal yang berkaitan dengan kematian, pemakaman, dan takdir kehidupan.

Setiap tokoh dalam cerita memiliki enigma dan pertanyaan yang saling berkaitan. Jawaban atas enigma menjadi surprise bagi pembaca. Nurgiyantoro (2010:136) menambahkan bahwa plot yang menarik, di samping mampu membangkitkan suspense, juga mampu memberikan kejutan jika kejadian yang dikisahkan menyimpang atau bertentangan dengan harapan pembaca.

Novel Ny. Talis (Kisah Mengenai Madras) menyuguhkan kode-kode yang menjadi pertanyaan karena jawaban yang diberikan selalu bertentangan. Sesuatu yang bertentangan itu menyangkut berbagai aspek yaitu alur, tokoh, cara berpikir tokoh, dan tindakan tokoh. Novel-novel Indonesia yang mampu menyuguhkan suspense dan surprise menarik selain $N y$. Talis (Kisah Mengenai Madras) adalah Belenggu, Burung-Burung Manyar. Novel-novel tersebut berani melawan arus (Nurgiyantoro, 2010:137).

\section{Kode Semes/Semantik}

Piliang (2012:162); Marwata, 2000:56) mengatakan bahwa kode semantik adalah kode yang berada pada kawasan penanda, yakni penanda khusus yang memiliki konotasi, atau penanda yang materialitasnya sendiri-tanpa rantai pertandaan pada tingkat ideologis-sudah menawarkan makna konotasi.dengan kata lain kode semantik adalah kode yang mengandung konotasi pada level penanda atau tanda-tanda yang ditata sehingga memberikan suatu konotasi.

\section{Makna Takdir Hubungannya dengan Kematian}

Makna takdir dan kematian menjadi pembahasan yang serius dalam novel ini. Sebagaimana pernah dilakukan pendedahan mengenai novel $\mathrm{Ny}$. Talis 
(Kisah Mengenai Madras) oleh Efendi (2009). Efendi berusaha mencari realitas kematian dalam novel tersebut dan beberapa hal yang berkaitan dengan kematian. Adapun kutipan data dalam novel tentang makna takdir hubungannya dengan kematian sebagai berikut.

"Almarhum ayah saya pegawai negeri. Sering pindah. Entah mengapa, ayah selalu dapat rumah dinas dekat makam. Ayah meninggal di situ, demikian pula ibu. Semua abang saya telah bekerja. Entah mengapa, masing-masing mereka juga dapat rumah dinas dekat makam."

"Takdir adalah takdir. Saya membeli rumah ini lewat iklan, sebelum saya mengenal Surabaya."

"Dan, di Bandung kamu tinggal dekat makam?"

"Begitulah, di luar kehendak saya." (Darma, 1996:59-60).

Takdir adalah penandaan dalam kode semantik. Takdir tidak terjadi secara kebetulan dan tidak pula dapat direncanakan. Menurut Wiwin takdir adalah ketetapan Tuhan. Setiap kali ia memiliki rumah selalu dekat makam, dengan demikian adalah ketetapan Tuhan. Semua itu di luar kehendak Wiwin.

Kematian menjadi penanda yang menarik untuk dimaknai secara luas. Dengan kata lain kematian dalam novel ini dimaknai dan dihubungkan dengan pernikahan. Hal ini dikarenakan, melalui pernikahan (perkawinan) itulah kelak akan melahirkan bayi-bayi. Bayi itu kemudian akan tua dan meninggalkan dunia. Dengan demikian kematian atau relaitas kematian dalam novel tersebut sangat dominan dalam pembahasan. Sebagaimana dilakukan Efendi (2009),menemukan realitas kematian dalam novel $N y$. Talis berupa (a) kematian tokoh, (b) tempat yang berhubungan dengan kematian, (c) proses pemakaman, (d) bayangan kematian, dan (e) makna kematian.Realitas kematian secara fungsional mendukung keutuhan unsur struktur novel, khususnya (a) tokoh dan penokohan, (b) latar, (c) alur, dan (d) tema.

\section{Makna Dominasi Maskulin dan Feminin}

Wacana dominasi maskulin dan feminin dalam sebuah karya sastra bukanlah hal asing. Baik karya sastra barat atau timur, sering kali mewacanakan dominasi maskulin atau feminis. Begitu juga dalam novel Ny. Talis (Kisah Mengenai Madras).

Sapaan Ny. yang melekat pada nama Ny. Talis adalah bentuk kata-kata feminin. Hanya Ny. Talis yang disematkan kata Ny. Tokoh lain tidak. Kata Ny. menjadi makna feminin karena melalui kata sapaan tersebut, seluruh suami yang pernah menikah dengan $\mathrm{Ny}$. Talis mengikuti nama Ny.Talis, seperti: suami Ny. Talis (suami pertama), dokter suami Ny. Talis (suami kedua), dan Ny. Talis tetap disapa Ny. Talis meskipun sudah tua.

Makna feminin juga terdapat pada tokoh Wiwin. Kejiwaan Wiwin sangat liar. Meskipun dia berada dalam konteks sosial yang bebas, dalam suatu titik tertentu, ia masih dapat menjaga harmonisasi etika dengan lingkungan sosial yang memaksanya untuk berbuat apa saja. Penanda semantik ini berarti keliaran adalah keteguhan jiwa dengan ambang batas tertentu. Di dalam keliaran yang dimiliki Wiwin, terdapat jiwa yang sangat teguh terhadap ajaran orang tua. Ia tidak mau mengecewakan orang tuanya. "Jiwa saya memang liar, Madras. Tapi saya adalah anak orang-orang yang bertaqwa.

Dominasi maskulin yang dilakukan Madras adalah bentuk superioritas atas laki-laki terhadap perempuan. Dominasi tersebut dilakukan dalam konteks sosial, perlakuan dan didasari sistem budaya 
(hubungan manusia dengan manusia) bahwa laki-laki lebih dominan dan berkuasa.Sebagaimana Walby (2014:28) bahwa laki-laki dalam konteks sosial budaya berada pada posisi dominan dan setiap perempuan dalam posisi subordinat.

\section{Makna Keterasingan dan Terkucil}

Tokoh Ny. Talis adalah tokoh yang terkucilkan dari kehidupan di sekelingnya, terutama keluarganya. Ketika ia masih kanak-kanak, ia tidak merasakan kehidupannya sebagai kanakkanak yang disayangi ayah dan ibunya. Ia seakan tersingkirkan dalam kehidupan keluarganya. Sejak lahir, ia dicap sebagai anak pembawa sial.

Apa yang disadarinya sejak dulu makin bertambah kuat. Satu-satunya jalan untuk keluar dari keterpencilan adalah kawin.(Darma, 1996:160).

Stigma manusia yang mengalami keterasingan sebenarnya juga muncul dari dalam diri Ny. Talis sendiri. Tembong yang menempel pada dadanya membuat ia menjadi manusia asing dan terkucil. Bahkan ia merasa terkucil ketika sudah menikah dengan suami Ny. Talis. Keterasingan itu muncul sebagai akibat kecemasan yang berlarut-larut (Yulianto, 2015).

\section{Kode Simbolik}

Pembahasan kode-kode simbolik dalam novelNy. Talis (Kisah Mengenai Madras) sebagai berikut.

\section{Simbol Antitesis Kehidupan}

Ada dan tidak ada adalah bentuk antitesis yang perlu dimaknai secara simbolis. Kehidupan selalu terkait dengan hukum-hukum seperti itu. Hal mengada dan tidak ada adalah bentuk kepastian tentang realitas. "Madras pernah menghadiri sebuah ceramah Guru Besar Matematika mengenai ada dan tidak ada, maka di bawah tulisan Santi Wedanti dia menulis, "Yang ada, itu ada. Yang tidak ada, itu ada" (Darma, 1996:37).

Hukum kepastian dalam hidup perlu ditafsirkan dengan memadukan hukum alam di dalamnya ada logikalogika kebenaran dan hukum sosial di dalamnya terdapat norma-norma sosial. Perpaduan dua macam hukum tersebut dapat digunakan untuk mencari hubungan sebab akibat dan antitesis tentang kehidupan.Simbol kehidupan selalu dikaitkan dengan kematian. Kematian tersebut disyaratkan oleh seekor burung aneh. Burung menjadi pembhubung antara kematian dan kehidupan.

\section{Simbol Realitas dan Takhayul}

Ny.Talis selalu percaya dengan Takhayul. Kode simbolik semacam inilah lantas membawa kesengsaraan hidup Ny. Talis. Sebagaimana kutipan di bawah ini.

"Rupanya Ny. Talis sangat percaya tahyul. Saya tidak suka. Dan karena itu, saya tidak mengoreknya lebih jauh. Kalau di berjalan, dia memperhitungkan irama kakinya. Kalau dai berbicara juga demikian. Juga kalau dia makan. Semua dia perhitungkan. Bukan untuk kepentingan kecantikan.. juga bukan untuk kepentingan sopan santun, tapi takhyul. Beberapa kali saya lihat dia komat kamit. Saya curiga itu bukan doa kepada Tuhan. Doa takhyul."(Darma, 1996:68).

Sebagai bentuk antitesis: doa Tuhan dan doa takhayul, Ny. Talis lebih percaya pada doa takhyul. Oleh karena itu, apa pun yang dilakukan selalu diperhitungkan. Doa takhayul itu bukan untuk kepentingan kecantikan atau sopan santun, tetapi benar-benar untuk takhayul belaka. Doa takhayul adalah doa untuk kesengsaraan dan penderiataan Ny. Talis.

Kode simbolik adalah kode yang mengatur aspek tak sadar dari tanda, dan dengan demikian merupakan kawasan dari psikoanalisis (Piliang (2012:162). 
Kode simbolik yang berisi antitesis takhayul dengan realitas, kebahagiaan dengan kesengsaraan, dan kehidupan merupakan struktur simbolik yang kemunculannya berulang-ulang. Repetisi kode simbolik tersebut mengacu pada tema-tema kehidupan dan kematian. Kehidupan dan kematian adalah jaringan stuktur yang kuat dalam novel tersebut.

Kebenaran realitas bertolak belakang dengan kebenaran takhayul. Realitas berangkat dari logika kebenaran rasional, sedangkan takhayul berangkat dari kesadaran kognitif yang diwariskan secara turun-temurun, sebagian lagi berangkat dari bisa diaspora agama. Selain itu, kepercayaan terhadap ada istiadat dan sistem nilai teologis (Sukatno CR, 2016:12).

Apa yang dilakukan Ny. Talis adalah percaya dengan kebenaran takhayul. Tembong yang ia miliki dianggap sebagai kesialan menjadi benar dalam konsepsi takhayul. Ekspresi ketakutan terhadap tembong karena dianggap sebagai pembawa sial, membuat Ny. Talis memiliki ketakukan yang luar biasa.

\section{Kode Proairetik}

Kode proairetik berkaitan dengan tindakan-tindakan dalam sebuah narasi dan antinarasi. Tindakan-tindakan para tokoh yang mengacu pada narasi-narasi cerita sebagai berikut.

\section{Proaresi tentang Kematian}

Kematian Wiwin berakibat pada tindakan Madras yang berkabung secara berlebihan. Ia terus merangsak ke arah Gresik, tempat Wiwin kecelakaan. "Demikianlah, malam itu Madras meninggalkan Surabaya. Kemudi mobilnya sudah dia ubah menjadi agak goncang. Kedua ban depan sudah dia ganti dengan ban lama yang sudah tipis. Dia sudah dapat menyimpulkan, bahwa mobil yang ditumpangi Wiwin dulu dalam kedaan semi" (Darma, 1996:199).

Tokoh-tokoh pasti melakukan tindakan tertentu. Tindakan yang dilakukan pasti didasari oleh alasan atau motivasi sesuai dengan tindakan itu. Tindakan apabila tidak didasari oleh motivasi, tindakan tersebut dikatakan tindakan absurd (Pujiharto, 2010:46).

\section{Kode Kultural}

Kode kultural adalah kode yang mengatur dan membentuk suara-suara kolektif dan anonim dari pertandaan, yang berasal dari pengalaman manusia dan tradisi yang beraneka ragam. Unitunit kode ini dibentuk oleh beraneka ragam pengetahuan dan kebijaksanaan yang bersifat kolektif (Widyatwati, 2015:61);(Piliang (2012:162).

\section{Moral Perempuan dalam Konteks Sosial Budaya}

Sistem budaya, hubungan manusia dengan manusia yang dimiliki Madras dan Wiwin bertolak belakang dengan Santi Wedanti. Santi Wedanti memiliki tata aturan yang ketat dalam menjalankan hubungannya dengan sesama manusia. Ia heran melihat Wiwin dan Madras saling menggerayang satu sama lain. Sebagaimana kutipan dialog berikut ini. "Santi Wedanti Mendelong" (Darma, 1996:137).

Di pihak lain, moral berkaitan dengan kejiwaan. Kejiwaan seseorang sangat dipengaruhi oleh kejiwaan sosial (psikososial) yang melatarbelakangi kehidupan seseorang. Begitu juga dengan Santi Wedanti. Kehidupan keras masa lalu yang pernah dialami Santi Wedanti membuat dia tidak dapat meninggalkan masa lalunya, termasuk sarkasme dalam berbahasa sebagaimana kutipan berikut ini.

Bukan hanya itu. Dari mulutnya keluar kata-kata kotor," Madrasi tai! Madrasi 
diancuk! Madrasi gendeng! Madrasi Anjing! Madrasi impoten!"

Masih banyak lagi kata-kata lebih kotor, lebih cabul, dan lebih menjijikkkan (Darma, 1996:144).

Kata-kata kotor, cabul, bahkan kotor, sering muncul ketika Santi Wedanti sedang marah. Kata-kata tersebut muncul secara otomatis akibat rangsangan dari lingkungan. Lingkungan keras sebagaimana telah membesarkan Santi Wedanti. Berdasarkan konteks sosial yang melingkupi Santi Wedanti, karakter sosial yang diacu Santi Wedanti adalah masyarakat kampung yang keras dan berbahasa kasar dalam konteks kehidupan sehari-hari. Kode kultural yang muncul dalam leksia ini adalah psikologi sosial.

\section{Mitos Takhayul dan Perdukunan}

Dalam pengetahuan modern, paranormal dan perdukunan adalah takhayul. Kebenaran dianggap tidak pasti dan tidak berdasarkan logika realitas. Meskipun demikian, Ny. Talis sangat percaya dengan takhayul dan perdukunan. Bagi sebagian masyarakat yang menyukai takhayul, mimpi adalah penanda kejadian masa depan. Kejadiankejadian masa mendatang lebih dipengaruhi oleh makna-makna mimpi.

Begitu juga dengan Ny. Talis. Ia menafsirkan mimpi bahwa kemudian hari dia akan menjadi kaya dan segera melangsungkan operasi tembongnya. Padahal, mengoperasi tembong adalah keinginan dia sejak dulu, karena tembong dipersepsikan sebagai pembawa sial atau malapetaka. "Mimpi pun datang. Dalam mimpi, dia sekonyong menjadi kaya. Maka, dalam mimpi, dia pegi ke dokter bedah yang sangat terkenal. Dokter pun membedah tembong gadis yang kelak bernama Ny. Talis"(Darma, 1996:149). Tembong besar dalam tubuh Ny. Talis juga dimaknai sebagai kesialan. Dengan demikian, tembong adalah sarana takhayul yang kemudian dipercayai sebagai pembawa malapetaka.

Kepercayaan terhadap mitos: perdukunan dan perjodohan dan bibit, bebet dan bobot dapat dipandang sebagai nilai kepribadian tokoh yang waspada dalam hidup, perjuangan dalam hidup, dan kesadaran berpikir futuristik. Melalui mitos-mitos tersebut, tokoh-tokoh memiliki visi ke depan untuk berpikir dinamis, meskipun baru sebatas teka-teki. Sebagaimana Sukatman (2009:311) di dalam kepercayaan tradisi lisan, takhayul, dan sebagaimya terdapat nilai-nilai kepribadian yang mencakup kewaspadaan, perjuangan, kesederhanaa, kebijakan, dan membuka pikiran futuristik.

Berbeda dengan mitos dan takhayul yang dipercayai Ny. Talis. Kepercayaan terhadap takhayul bukan untuk memdapatkan kewaspadaan, kebijaksanaan, dan membuka pikiran futuristik. Kerpercayaan terhadap tahayul justru membelenggu Ny. Talis ke dalam kesengsaraan. Ny. Talis sulit sekali keluar dari belenggu takahayul karena masa lalunya, sebagaimana masa lalu ayah dan ibunya mengajari kepercayaan terhadap takhayul. Kepercayaan yang diajarkan ayah dan ibu Ny. Talis membuat dia menyelaraskan dirinya dengan ajaran mitos yaitu menyiapkan sesaji, menghafal rapalan doa-doa tapi bukan untuk Tuhan, bahkan meniru dewa-dewa dan leluhur untuk mendapatkan keselamatan. Sebagaiman Pusposari (2014:64) mengatakan bahwa ajaran mitos dapat dilakukan dengan cara meniru cara leluhur untuk mencapai keselamatan. Begitu juga hal semacam itu dilakukan oleh Ny. Talis.

Kode kultral yang lain dan menjadi sentral dalam novel Ny. Talis (Kisah Mengenai Madras) adalah psikologi sosial. Kejiwaan tokoh-tokoh sangat dipengaruhi oleh kondisi kejiwaan 
sosial sebagai latar belakang perilaku tokoh dalam cerita. Konteks sosial yang diacu adalah masyarakat kota Surabaya. Pengacuan konteks sosial tersebut kemudian diintegrasikan dalam watak dan perilaku yang kuat dalam diri tokohtokoh.

Dekonstruksi kondisi sosial budaya yang dilakukan oleh pengarang, membawa pembaca untuk menafsirkan kembali kondisi sosial budaya yang terus bergerak, melaju, dan dinamis. Melalui dekonstruksi tersebut, pembaca dihadapkan pada lambang-lambang dan makna baru.

Makna-makna baru yang lebih leluasa ditafsirkan adalah makna kematian dan hal-hal yang berkaitan dengan kematian seperti: rombongan iringan jenazah, makam, burung aneh, dan takdir. Beberapa makna tersebut ditafsirkan secara mendalam dalam novel Ny. Talis (Kisah Mengenai Madras).

Bagi Barthes dalam Piliang (2012:163), proses berkarya adalah proses saling menyilangnya lima kode tersebut, yang menciptakan semacam jaringan kode-kode, yang disebut topos.

Penyingkapan kode di dalam pengertian semiotika, secara sederhana berarti pencarian kode tertentu, yang membentuk suatu ekspresi bahasa, dan dengan demikian berfungsi sebagai pembentuk makna dari ekspresi tersebut. Penyingkapan kode dengan demikian, berarti pencarian makna-makna yang dikodekan (Piliang, 2012:163).

\section{SIMPULAN DAN SARAN}

Berdasarkan hasil penelitian dan pembahasan yang dilakukan mengenai Kajian Semiotika dalam novel $N y$. Talis (Kisah mengenai Madras) karya Budi Darma, tentang kode-kode semiotik dalam karya sastra dapat disimpulkan bahwa kode-kode semiotik dalam novel Ny. Talis (Kisah Mengenai Madras) dihubungkan oleh beberapa leksia umum dalam novel. Leksia penghubung jaringan tersebut tidak lain adalah makna pertandaan tentang kematian dan hal-hal yang berkaitan dengan kematian. Selain itu, realitas kehidupan yang mengacu pada kematian.

Berdasarkan simpulan tersebut, penelitian ini dapat dikembangkan ke ranah disiplin ilmu antardisiplin. Misalnya menggabungkan antara semiotika sastra dengan semiotika budaya atau yang lain yang diterapkan dalam karya di luar sastra. dengan harapan, penelitian semiotika sastra dapat berkembang dengan menggandeng disiplin ilmu yang lain.

\section{DAFTAR PUSTAKA}

Barthes, Roland. 2002. S/Z. United Kingdom: Blackwell Ltd.

Barthes, Roland. 2007. Petualangan Semiologi. Diterjemahkan oleh Stephanus Aswar Herwinarko. Yogyakarta: Pustaka Pelajar.

Barthes, Roland. 2011. Mitologi. Yogyakarta: Kreasi Wacana.

Barthes, Roland. 2012. Elemen-Elemen Semiologi. Diterjemahkan oleh Kahfi Nazaruddin. Yogyakarta:Jalasutra.

Darma, Budi. 1996. Ny. Talis (Kisah Mengenai Madras). Jakarta: Grasindo

Efendi, $\quad$ Anwar. 2009. RealitasKematiandalam NovelNy. Tallis(KisahMengenaiMadras) Tesis tidakditerbitkan. Yogyakarta: Universitas Negeri Yogyakarta.

Endraswara, Suwardi. 2011. Metodologi Penelitian Sastra: Epistemologi, Model, Teori, dan Aplikasi. Yogyakarta:CAPS.

Luxemburg, Dkk. 1992. Pengantar Ilmu Sastra. Diindonesiakan oleh Dick Hartoko. Jakarta. Gramedia. 
Nurgiyantoro, Burhan. 2010. Teori Pengkajian Fiksi. Yogyakarta: Gajah Mada University.

Piliang, Yasraf Amir. 2012. Semiotika dan Hipersemiotika: Kode, Gaya, dan Matinya Makna. Bandung: Matahari.

Pujiharto. 2010. Pengantar Teori Fiksi. Yogyakarta: Jurusan Sastra Indonesia FIB UGM.

Pusposari, Dewi. 2014. Mitos dalam Kajian Sastra Lisan. Malang: Pustaka Kaiswaran.

Ratna, Nyoman Kutha. 2010. Metodologi Penelitian Kajian Budaya dan Ilmu Sosial Humaniora pada Umumnya. Yogyakarta:Pustaka Pelajar.

Stanton, Robert. 2012. Teori Fiksi. Diterjemahkan oleh Sugihastuti. Yogyakarta: Pustaka Pelajar.
Suhariyadi. 2014. Pengantar Ilmu Sastra. Lamongan. Pustaka Ilalang.

Sukatno CR, Otto. 2016. Nalar Serta Rasionalitas Mistik dan Ilmu Gaib. Yogyakarta: Pustaka Pelajar.

Walby, Sylvia. 2014. Teorisasi Patriarki. Diterjemahkan oleh Mustika K. Prasela. Yogyakarta: Jalasutra.

Widyatwati, Ken. 2015. Cerpen Faruk "Bus Kota" dalam Semiotik Roland Barthes. Jurnal Humanika, Volume 22 No. 2 tahun 2015. Semarang: FIB Universitas Diponegoro.

Yulianto, Mochammad Ichlasul. 2015.Citra Perempuan dalam Novel Ny. Talis (Kisah Mengenai Madras) Karya Budi Darma: Kajian Psikoanalisis. Tesis tidak diterbitkan. Lamongan: Program Pascasarjana Universitas Islam Darul Ulum. 